\title{
Surgical Hand Scrub: Lots of Water Wasted
}

\author{
A. Ahmed \\ Department of Surgery, Ahmadu Bello University Teaching Hospital, Zaria, Nigeria \\ Reprint requests to: Dr. Adamu Ahmed, Department of Surgery, Ahmadu Bello University Teaching Hospital, \\ Zaria, Nigeria. E-mail: mrahmed1010@yahoo.com \\ This paper was presented at the $2^{\text {nd }}$ Annual Congress of Association of Surgeons of Nigeria, Abakaliki, 31 March - 3 April 2004.
}

\begin{abstract}
Background: Surgical hand scrub (SHS) is an important antisepsis measure before participating in surgical operation. It reduces the risk of microbial contamination of the surgical wound by skin flora. SHS is usually performed in a scrub sink with taps that have hand operated handles. During the scrub process large volume of water is wasted. The aim of this study was to determine the volume of water used during SHS in comparison to the actual volume necessary.

Method: Unknown to them various cadre of the operation team were timed during their first scrubbing of the day for scheduled operations. Duration of scrubbing (ST) and that during which the hands were being washed with flowing water (WT) were recorded. The amount of water flowing through the tap per minute was also recorded. Using the mean ST, WT and water flow per minute the total volume of water used during scrubbing and that necessary to wash the hand were calculated.

Results: Overall, the ST ranged between 3 and 7 minutes with a mean of $4.8 \pm 0.5$ SD minutes. Mean WT was $1.4 \pm 0.4$ SD minutes. The mean water flow was $4,217 \mathrm{mls}$ per minutes. The volume of water used per scrubbing was 20.2 litres while only 5.9 litres was used for washing the hands. Between January and December 2002, the volume of water used for scrubbing was 200,283 litres while only 58,498.5 litres $(29.2 \%)$ was necessary.

Conclusion: Plenty water is wasted during SHS. Reducing the amount of water flowing unused would provide cost saving to the hospital. The use of taps operated with foot pedal would reduce the waste.
\end{abstract}

Key words: Operation, hand scrub, water, wastage

\section{Résumé}

Introduction : Brosse chirurgicale pour se frotter les mains (BCM) est une mesure antisepsie importante avant une participation dans une opération chirurgicale. Elle reduit le danger de la contamination microbiale des blessures chirurgicales par la flore de peau. Le BCM est opéré dans un evier à se frotter avec des robinets qui a des mains avec des manches d'opération. Pendant le processus de se frotter les mains une grande quantité de l'eau est perdue. L'objet de cette étude était de décider le volume de l'eau utilisée pendant le BCM par rapport au volume normal exigé.

Méthodes: Chaque cadre des équipes d'opération ne savaient pas que l'on les avait mesuré le temps pendant la prémière fois de se frotter de la journée pour des opérations calculées. La durée de se frotter (DF) et celle pendant laquelle les mains se sont lavées avec de l'eau au cours rapide (LC) ont été notées. La somme de l'eau qui coule dans le robinet par minute était également notée. Avec l'utilisation du moyen, DF, LC et l'eau coulé par minute le volume total de l'eau utilisée pendant le frottement et le volume total nécessaire pour se laver les mains ont été calculés

Résultats : Dans l'ensemble, la (DF) varie de 3 à 7 minutes avec un moyen de 4,8+-0,5 SD minutes. Moyen LC était 1,4+-0,4 SD minutes. Le moyen de coulement de l'eau utilisée par le frottement était 20,2 litres tandis que 5,9 litres seulement était utilisé pour se laver les main. Entre janvier et décembre 2002, le volume de l'eau utilisée pour le frottement était 200,283 litres tandis que 58, 496,5 litres seulement soit $29,2 \%$ était nécessaire.

Conclusion: Beaucoup de l'eau est gaspillée pendant BCM. Ce qui a réduit la quantité de l'eau qui coule sans être utilisée et ça va donner la somme que l'on peut garder pour l'hôpital. L'utilisation des robinets opérés par la pédale du pied va réduire le gaspillage.

Mot-clés : Opération, brosse pour se frotter les mains, de l'eau, gaspillage 


\section{Introduction}

Surgical hand scrub (SHS) is the process of removing as many microorganisms as possible from the hands and arms by mechanical washing and chemical antisepsis before a surgical procedure. During the process transient microorganisms that are loosely attached to the skin surface are almost completely removed by thorough washing with detergent and water. Microorganisms in hair follicles and sebaceous glands are more adherent and therefore more resistant to removal. ${ }^{1}$ Their growth is inhibited by the chemical phase of the surgical scrub. ${ }^{1}$ Previous reports have emphasized the necessity of strict monitoring of disinfection and sterilization of operation theatres. ${ }^{2,3}$

In developing countries the cost of water is rising due to increasing scarcity of water resources and high competition between water use and environmental degradation. $^{2}$ In these places it is not uncommon to delay or cancel operation due to lack of water. Lack of water in the theatre was the cause of prolonged delay in $5.1 \%$ of emergency operations in one report. ${ }^{4}$ In our hospital SHS is performed in an individually enclosed scrub sink with taps that have hand (or elbow) operated handles (Figure 1). In order to reduce the risk of contaminating the hands during cleansing, the tap once put on is allowed to flow conteneously until the end of scrubbing when it is put off with the elbow. Obviously, reducing the amount of water flowing unused during the scrub procedure would provide cost saving to the hospital. The aim of this study was to evaluate the volume of water used during SHS in relation to the volume actually necessary.

Figure 1: Scrub sink with hand operated tap

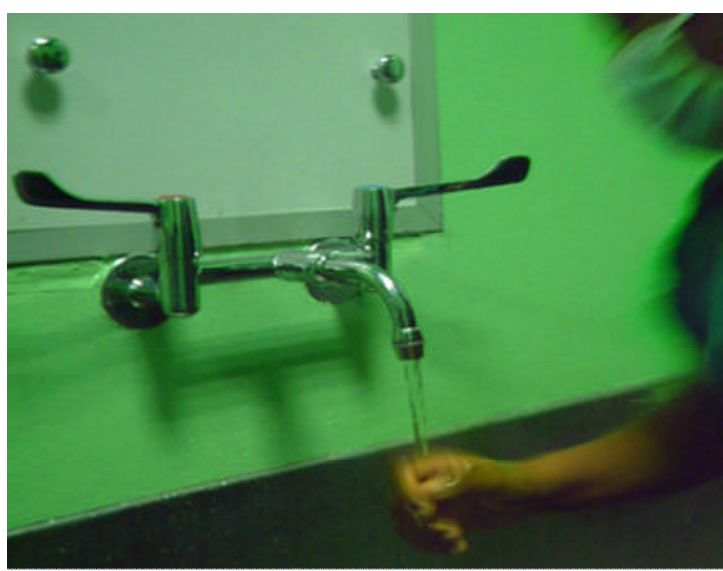

\section{Subjects and Methods}

This prospective study was conducted in the Department of Surgery, Ahmadu Bello University Teaching Hospital Zaria, Nigeria. It was a blinded study in which the subjects were not aware they were timed during scrubbing. Different grades of members of the operation team were observed scrubbing before participating in operations. Subjects were randomly selected and were observed during their first scrubbing of the day for scheduled surgical operations. Duration of scrubbing was measured with a standard stopwatch. Scrub time (ST) defined as the time during which the water was flowing for the purpose of the procedure was measured. Wash time (WT) defined as the time during which the hands were washed with flowing water was also recorded. A total of 126 observations were made on 63 personnel. Each personnel was timed at 2 different occasions and the mean values of ST and WT were recorded.

In order to determine the amount of water that flow through the tap per minute we took an average of 3 readings each at low and medium flow. Medium flow was defined as that above which water would splash on the floor and the body of the person scrubbing. The average flow rate of water was determined at low and medium flow because that was the range at which water flows when majority of personnel were scrubbing. The overall mean flow per minute was determined. Using the overall mean ST, WT and water flow per minute the total volume of water used and that necessary to wash the hands were calculated.

\section{Results}

Overall, the ST ranged between 3.0 and 7.0 minutes with a mean of $4.8 \pm 0.5$ SD minutes. Mean WT was $1.4 \pm 0.4 \mathrm{SD}$ minutes. The mean ST and WT for each category of theatre personnel are shown in table 1. At low flow, 3,196 mls of water was flowing through the tap while at medium flow 5,238 mls was flowing (mean flow 4,217 $\mathrm{mls} / \mathrm{min}$. The mean volume of water used for each scrubbing was 20.2 liters while only 5.9 liters was used for washing the hands.

From January - December 2002, 3,305 operations were performed in the theatre. Assuming an average of 3 theatre personnel scrubbing per case, the total volume of water used for scrubbing was 200,283 liters when only $58,498.5$ liters $(29.2 \%)$ was necessary.

Table 1: Scrub and wash times of observed theatre personnel

\begin{tabular}{lllll}
\hline Personnel & Scrub time/min & \multicolumn{3}{l}{ Wash time/min } \\
\hline & Range & Mean \pm SD & Range & Mean \pm SD \\
\cline { 2 - 5 } Consultant $(\mathrm{n}=13)$ & $3.0-6.1$ & $4.8 \pm 0.6$ & $0.8-2.3$ & $1.4 \pm 0.4$ \\
Senior registrar $(\mathrm{n}=10)$ & $3.2-7.0$ & $5.5 \pm 0.4$ & $0.8-2.7$ & $1.7 \pm 0.2$ \\
Registrar $(\mathrm{n}=15)$ & $3.0-6.4$ & $3.7 \pm 0.8$ & $0.7-2.4$ & $1.4 \pm 0.4$ \\
Scrub nurse $(\mathrm{n}=25)$ & $3.1-7.0$ & $5.0 \pm 0.6$ & $0.9-2.8$ & $1.6 \pm 0.5$ \\
\hline Total $(\mathrm{n}=63)$ & $3.0-7.0$ & $4.8 \pm 0.5$ & $0.7-2.8$ & $1.4 \pm 0.4$ \\
\hline
\end{tabular}

SD: standard deviation 


\section{Discussion}

In the theatre environment the principles of decontamination and asepsis constitute the major health and safety policy and protocols. In this study the shortest scrub time was 3 minutes. Scrubbing for 3 minutes produced statistically significant decrease in bacterial count than scrubbing for 2 minutes. ${ }^{5,6}$ Our mean scrub time of 4.8 minutes agrees with 3 to 5 minutes recommended by others. ${ }^{6}$ A mean WT of 1.4 minutes shows that water was used in washing the hands in only about one-third of the ST. Of the 200,283 liters used during the study only $58,498.5$ liters $(29.2 \%)$ was necessary.

The cost of water supply and sewage drainage would significantly reduce if we reduce the water wasted during the scrub procedure. In addition, more judicious use of water would make it more available thereby limiting the delays and cancellations of operations due to lack of water in the theatre. Several efforts have been made to reduce the cost of SHS. Installing electronic eye taps into theatres have significantly reduced the amount of heated water flowing unused during the scrub procedure. 7 However the volume saved did not justify the cost of these taps. Surgical hand disinfections which consist of application of alcohol-based hand rub into dry hands without water have been shown to have immediate efficacy that was similar to SHS and reduced cost by $67 \% .^{8}$ The use of light-sensor activated water taps has also been recommended ${ }^{7}$. In our environment where electricity supply is not regular, we recommend taps that can be operated with foot pedals. This would reduce the volume of water flowing unused and the risk of contaminating the hands at the end of the scrub procedure.

This study has shown that large volume of water is being wasted during SHS. This can have a major implication on cost and quantity of water used particularly in developing countries. The use of taps operated with foot pedals would significantly reduce the waste.

\section{References}

1. Gunter K, Axel K. Epidemiological background of hand hygiene and evaluation of the most important agents for scrubs and rubs. Clin Microbiol Rev 2004; 17: 863-893

2. Chanda R, Grover M, Sharma M, et al. An outbreak of post surgical wound infection due to Mycobacterium abscessus. Paediatr Surg Int 1998; 13: 406-410

3. Shiraishi T, Nakagawa Y, Mastubara H, et al. A survey of the appropriate use of antiseptic agents in operating rooms of several key health care facilities: a comparison between surveys in 2000 and 2004. Dermatology 2006; 212: 15-20

4. Eguma SA, Kalba DU. An audit of emergency anaesthesia and surgery. Nigerian Journal of Surgical Research 2003; 5: 140-147

5. Khan A, McLaren SG, Nelson CL. Surgical hand scrub practices in orthopaedic surgery. Clin Orthop Relat Res 2003; 414: 65-68

6. Wheelock SM, Lookinland S. Effect of surgical hand scrub time on subsequent bacterial growth. AORNJ 1997; 65: 10871092

7. Ross C. What cause ritual? $\mathrm{Br} \mathrm{J}$ Theatre Nurs 1994; 4: 11-14

8. Tavolacci MP, Pitrou 1, Merle V, Haghighat S, Thillard D, Czernichow P. Surgical hand rubbing compared with surgical hand scrubbing: comparison of efficacy and cost. J Hosp Infect 2006; 49: 257-261 